\title{
Unfolding nomadism? A feminist political ecology of sedentarization in the Attappady Hills, Kerala
}

\author{
Deepa Kozhisseri ${ }^{1}$ \\ Sudhir Chella Rajan \\ Indian Institute of Technology Madras, India
}

\begin{abstract}
The landscape of the Attappady Hills in the Nilgiri range of Kerala, South India, is home to several Adivasis or indigenous peoples and settler communities, and has had intermittent cycles of agrarian crisis and sufficiency, according to colonial accounts from the early 20th century. Since the 1970s, rapid sedentarization of hunting-gathering communities, expanding capitalist markets, conservation projects, and sizable development interventions have contributed to agrarian and nutritional distress. There is a simultaneous process of adopting capitalist market forms and holding on to communal structures, along with manifestations of patriarchy, and resistance through gender struggles within the household and through community mobilization. Adivasis in the region seem to be undergoing processes of being simultaneously alienated from the forest and rediscovering connections to their land and the non-human world. By highlighting the material aspects with relational ecological ties and patriarchal manifestations with rural women's movements, this article proposes the relevance of nomadic movement in interpreting gender and environment subjectivities that have a bearing on these communities' future foodscapes and the rest of their landscape. We point to a continuous process of becoming, a 'feminist politics of the earth' in this landscape and extend the gendernature debate beyond dualisms and liminality by highlighting fluid dialectical processes within a feminist political ecology framework.
\end{abstract}

Keywords: Agrarian transitions; sedentarization; feminist political ecology; nomadic theory

\begin{abstract}
Le paysage des collines d'Attappady dans la châne de Nilgiri au Kerala, dans le sud de l'Inde, abrite plusieurs Adivasis ou peuples autochtones ainsi que de nouveaux immigrants. Elle a connu des cycles intermittents de crise agraire et d'autosuffisance, selon les récits coloniaux du début du XXe siècle. Depuis les années 1970, la sédentarisation rapide des communautés de chasseurs-cueilleurs, l'expansion des marchés capitalistes, les projets de conservation et les interventions de développement importantes ont contribué à la détresse agraire et nutritionnelle. Il y a eu un processus simultané d'adoption de formes de marché capitalistes, tout en s'accrochant aux structures communautaires, ainsi que des manifestations de patriarcat et de résistance à travers les luttes de genre et la mobilisation communautaire. Les Adivasis de la région semblent subir des processus d'aliénation simultanée de la forêt et de redécouverte de liens avec leur terre et le monde non humain. En mettant en évidence les aspects matériels liés aux liens écologiques relationnels et aux manifestations patriarcales avec les mouvements de femmes rurales, cet article propose la pertinence du
\end{abstract}

\footnotetext{
${ }^{1}$ Deepa Kozhisseri, Research Scholar, Humanities and Social Sciences, Indian Institute of Technology Madras, Chennai 600036, India. Email: kozhisseri "at" gmail.com. Sudhir Chella Rajan, Professor, Humanities and Social Sciences, IndoGerman Centre for Sustainability, Indian Institute of Technology Madras, India. Email: scrajan "at" iitm.ac.in. Acknowledgements: The authors are grateful to the many informants with whom the lead author spent considerable lengths of time over the course of three years of visits and extended stays in Attappady, and Kerala state departments for facilitating access to forest areas inhabited by Indigenous communities, especially the mobile medical team for collaboration during fieldwork. Funding was from a part-time Research Assistantship from the Ministry of Human Resource Development, Government of India. We are also indebted to the editor of JPE and anonymous referees for their careful reading of a previous draft, and detailed comments.
} 
«mouvement nomade» dans l'interprétation des subjectivités de genre et d'environnement qui ont une incidence sur les futurs paysages alimentaires de ces communautés et le reste de leur paysage. Nous signalons un processus continu de devenir, une «politique féministe de la terre» dans ce paysage et étendons le débat genre-nature au-delà des dualismes et de la liminalité, en mettant en évidence des processus dialectiques fluides dans un cadre d'écologie politique féministe.

Mots clés: transitions agraires; sédentarisation; écologie politique féministe; théorie nomade

\section{Resumen}

El paisaje de las montañas de Attappady de la cordillera Nilgiri de Kerala, en el sureste de la India, es el hogar de varios adivasis o población indígena, como también de comunidades colonizadoras. La zona ha tenido ciclos intermitentes tanto como de crisis, como de suficiencia agraria, de acuerdo con los registros coloniales de principios del siglo XX. A partir de la década de 1970, la rápida sedentarización de comunidades cazadoras-recolectoras, la expansión de mercados capitalistas, proyectos de conservación y notables intervenciones de desarrollo, han contribuido a problemas agrarios y alimentarios. Ahí se han presentado una simultaneidad de procesos entre la adopción de formas del mercado capitalista y el apego a las estructuras comunales, junto a manifestaciones patriarcales y de resistencia a través de luchas de género al interior de los hogares y a través de la movilización comunitaria. La población adivasi de la región parece estar experimentando al mismo tiempo procesos de ser alienación respecto al bosque, como del redescubrimiento de conexiones con su tierra y el mundo no humano. Al destacar el aspecto material con vínculos ecológicos relacionales y manifestaciones patriarcales con movimientos rurales de mujeres, este artículo apunta a la importancia del movimiento trashumante para interpretar las subjetividades del género y el medio ambiente que tienen una articulación con los paisajes gastronómicos futuros de estas comunidades, así como con el resto de sus panoramas. Apuntamos a un continuo proceso de conversión, una 'política feminista de la tierra’ en este paisaje, y a ampliar el debate genero-naturaleza más allá de dualismos y liminalidad al destacar procesos dialécticos fluídos dentro de un marco de ecología política feminista.

Palabras clave: transiciones agrarias, sedentarización, ecología política feminista, teorías de trashumancia

\section{Introduction}

Saroja $^{2}$, an Adivasi farmer belonging to the Kurumba community in the Attappady hills in Kerala, recalls that it has only been 14 years since she started eating rice, the staple food of South India. Until then, her family grew millet, sorghum, various beans, tubers, and pumpkin in the forest. Occasionally, men of the household hunted for wild meat. Today she and her husband grow banana for the market and purchase rice for the household. Saroja and many of her neighbors switched from millet cultivation to banana, which has not yielded expected harvests and instead pushed them into debt. They are now dependent on the market and the state for subsidized rice at government-sponsored public distribution outlets. Saroja and other Adivasis like her moved to settled farming in recent history due to contact with settlers from the plains of Tamil Nadu and Kerala. In her region and elsewhere in the hills, Adivasis lost most of their riverine land over the course of more than a century, and the landscape also became severely denuded.

In February 2018, a homeless 27-year-old Kurumba man, Madhu, from the forest village of Chindaki, was beaten to death by a mob of settlers for allegedly stealing rice from a local grocery store (The Hindu 2018a; Outlook 2018). In the following days, Madhu's sister Sarasu, a nursery schoolteacher from Chindaki, appeared inconsolable. "He was always in the forest, and even when we brought him home he would escape back into the forest. He was never hurt by wild animals but rather by settlers in the end", she said. Sarasu was five months pregnant at the time and had to be admitted to a hospital, as her fetus was not showing the appropriate development parameters. A few weeks later, she delivered a stillborn child.

\footnotetext{
${ }^{2}$ Names of some informants who participated in the research have been changed to protect their identity. In Attappady the Irulas, Mudugas, and Kurumbas are all termed 'Scheduled Tribes' in the official designation in the Indian constitution. Communities were often categorized as tribal by reason of the localities in which they were found at the time of the first ethnographic survey. They now call themselves Adivasi or original inhabitants. "Adivasi" is an appropriated term associated with the broader set of such peoples that tries to overcome troublesome words like "aboriginals", "native groups", "tribal" or even "forest peoples." See also Banerjee (2016).
} 
In stark contrast with the celebrated economic miracles of East Asia in the 1980s and 1990s, the southern state of Kerala in India has been famously characterized as a "paradox" or "exception" because its policies generated substantially enhanced quality of life that was accompanied by only meager increases in average income. The state was a conundrum for scholars and political observers in the 1970s, with its modest level of economic development, but high social development indicators of improving health literacy, reducing infant and maternal mortality, and falling birth rates (Devika 2010). The state's development strategy (often simply termed the "Kerala model" - Parayil 2000) served to change the paradigm of development from a single dimension of growth, as measurable increases in monetary income, to non-monetary forms of value making up individual and collective welfare. The model helped expand the developmental state's mandate to provide means for economic output along with bodily "functionings", including care and the conditions for learning and personal autonomy. In Kerala, the net outcome was a dramatic reduction in mortality rates, a higher female-male ratio than the Indian average, and close to 100 percent literacy among women and menall with a lower GDP per capita than the Indian average. For the ruling Communist Party, the state's strategy was an innovation based on principles of social and economic liberation, understood in terms of improvements in average indicators (health and education) rather than as broader changes in the social landscape. Accordingly, the state's focus was on public action to empower especially women through education, legal rights, and enlightened egalitarian politics (Drèze and Sen 1990).

There are, however, less buoyant readings of the Kerala model. J. Devika, for instance, points out that the so-called "people's state" was not above conferring special benefits to upper castes by exploiting Dalits (untouchables or outcasts) and Adivasis, who were often deprived of productive assets and remained at the fringes of communist organizational infrastructure. Land reforms were frequently carried out at the expense of Adivasi communities, and a type of "secularized casteism" continued even as social inequalities were glossed over (Devika 2010). Tellingly, Adivasi communities in Kerala have long been disproportionately prone to high morbidity from respiratory and diarrheal skin infections, malnutrition, anemia, and more recently, lifestyle diseases such as diabetes, hypertension and cardiac disorders (Nalinam 2016). Adivasi infant mortality rate throughout the state is still higher than that of the general population and life expectancy is lower and adults face problems of alcoholism and poor nutrition (Raman 2010; Eddison and Devi 2019). In 2013, there was an upsurge in instances of infant mortality (35 per 1000 live births from an average of around 15 in previous years) among Adivasis in Attappady. This represented a historic inequity in a state whose low infant mortality rate (IMR) puts it well ahead of the rest of the country (10 in 2016 in Kerala, compared with the national average of 34, according to Niti Aayog 2018; see also Xaxa et al. 2014: 316317).

In addition to their perilous health, with alcoholism often adding to poor nutrition and associated comorbidities, Adivasis face political challenges associated with the fact that their homelands are frontier regions and among the most backward in the state of Kerala (e.g., The Hindu 2013; The Hindu 2018b). The 2013 spike in infant mortality among the Adivasis in Attappady was accompanied by poor maternal health, high rates of alcoholism and domestic violence (Manikandan 2014). Still, a view that treats Adivasis as "victims" of Kerala's development experience has been contested as it does not recognize comparative statistics with the rest of India, ignores their historical political experience and multifaceted relationship with the state, and how at least some of them employed the resources of development to improve their conditions (Steur 2009). Indeed, Adivasi lives are now comparatively better, especially in terms of their purchasing power, even if it is meager for most. Nevertheless, stark injustices continue to characterize many of the social conditions of their lives, and appear conspicuously in their current ways of living against their deep roots in the changing political ecology of the region (Nirmal 2017).

This article focuses on the earth-gender politics of transitions in agrarian practices in Attappady. We argue that changes in land-use practices and food sufficiency are socio-ecological and gendered and that they need to be understood, with all their complexities, as dialectical and fluid processes. Second, they also require rethinking of multiple subjectivities intersecting human-nature relationships, which have conventionally been viewed through frozen binaries such as traditional-modern agriculture, machinery vs. nature, and so on (Kunze 2017; McDowell 2018). We pursue a dialectical path that unpacks the conditions in which capitalism and markets coexist with traditional ecological knowledge. Corroborating similar findings from elsewhere, 
we point out that in Attappady, too, gender is a process in which gender subjectivities are produced and constituted by relations of power that operate through the biophysical world. In spite of familiar ways in which patriarchy is manifested in infant mortality, alcoholism, domestic violence, and a paternal state, we suggest that gender mobilization in some ongoing revitalized shared food and healing practices might serve to operate as a type of ecofeminist politics in the making (Nightingale 2006; Elmhirst 2011; Edison and Devi 2019). Furthermore, despite its powerful role in transforming Attappady landscapes and lifestyles, state action in Attappady cannot be viewed as the authoritative arrangements of a monolithic actor but rather as different modes of governance (or governmentality) mediated complexly through land relations, capitalist agriculture and community-scale mobilization.

The embodied materialism of the Adivasis in Attappady, especially women, is itself oddly disjointed; while some have voluntarily sought to participate in capital markets, there is a renewed affirmation among many of their communal forms of reproduction and ecological practices. Several women have been central to the recuperation of the commons, using community kitchens and cultural development of intra- and interclan associations to form kernels of change. They have fed their families from their fields and gardens, collected herbs, cured their kin, cooked traditional foods in community kitchens, and partly revived barren hills with afforestation. While Adivasi women face virulent patterns of patriarchy in the form of land encroachment by settlers and domestic violence, an anti-alcohol social movement led by Adivasi women in Attappady portends an emergent progressive politics of possibilities.

We take infant mortality and hunger in Attappady as starting points but pivot to their relationship toward a broader swathe of concerns relating to the political ecology of food in the region. By taking this route, we intend to add a note to the literature on food sovereignty in Adivasi regions by focusing on how development deficits are experienced. We thereby hope to stretch the meaning of the word "malnutrition" to fully embody what it means to a community mired in the shifting politics of food (cf. Whatmore and Thorne 1997). We try to interpret the life-worlds of a few mothers in the context of their land, food practice, and social interactions before they became these statistics, and also ask what might have happened to food cultures and food sovereignty among the people of the forest we had contact with. If there are opportunities to transform these conditions, what might they involve? While we draw on ethnography from the Attappady Hills of Kerala, we are optimistic that some of our findings are relevant to other contexts that have marginalized populations alongside the commodification of nature in both the Global South and North.

Our conceptual frames intersect across themes in feminist political ecology (FPE) and emerging theories of collaborative or adaptive governance, with all the tensions implied in this theoretical fusion. Gender and nature theories have become especially relevant in the Anthropocene and continue to be reinvented through new concepts. To unpack the dense rhizomatic factors at work, we adopt the idea of nomadic thought that is continuously in a process of becoming (Braidotti 2011). We invoke a rooted networks approach where Adivasis are at the center of some networks but also typically engaged in subordinate or dominant relations with nodes that include human and non-human actants, including institutional arrangements, such as state agencies, community organizations, and capital markets. This challenges the idea of indigeneity as rooted in place alone instead shows the existence of other socio-technical networks of rootedness (Cantor et al. 2018; Nirmal 2017; Rocheleau 2001, 2015; Rocheleau and Nirmal 2015). This approach also highlights that land itself_-spaces, migration routes and movement, plant and soil diversity, and other related processes - is part of the networked body of the Adivasi (Nirmal 2017). Such conceptual analysis makes possible the extension to further considerations of the dialectics of capitalism and affective political ecology, patriarchy, and gender subjectivity in Adivasis' lives.

This article is divided into five sections: this introduction, relevant literature, methods, findings, and conclusion. In the following subsection, and still part of the introduction, we locate our study in Attappady Hills and outline the historical context of change in land-use practices among Adivasis. In Section 2, we outline some findings from FPE and nomadic theory to interpret assemblages of capital flows and ecological practices, patriarchy and gender mobilization. Section 3 describes the ethnographical process by which we carried out the study. Section 4 presents our findings; while capital and state have eroded the sense of collective among communities that transitioned to settled agriculture in recent history, there are ways in which state resources, in particular, might be repurposed for building shared foraging and cooking practices to 
reclaim food sovereignty and healing. In Section 5, we conclude by proposing modest policy direction on the basis of our conceptual argument and findings and raise additional questions on the assemblage of humannature and feminist-post-human relationships.

\section{Locating the Attappady Hills}

The Attappady Hills are part of the Western Ghat rainforests, one of the biodiversity hotspots of the world (Figure 1). They are today part of Kerala state, in southwestern India. The 1901 census shows that the indigenous people of the Irula, Muduga, and Kurumba communities were the sole inhabitants of Attappady. While it was a tribal region until the 1950s and early 1960s, settlers then became numerically preponderant. In 1962, after the Kerala State Planning Board assessed Attappady as the most backward block in the state, the government declared it an "Integrated Tribal Development Block." Recent estimates are that Irulas number 26,908, Mudugas 3,497, and Kurumbas 2,551, bringing the tribal population up to 32,956, or about 45 percent of the total population in the region, compared to 1951, when it was 90 percent tribal (ITDP 2018). The bulk of the population is made up of Malayalee and Tamil settlers from the plains.

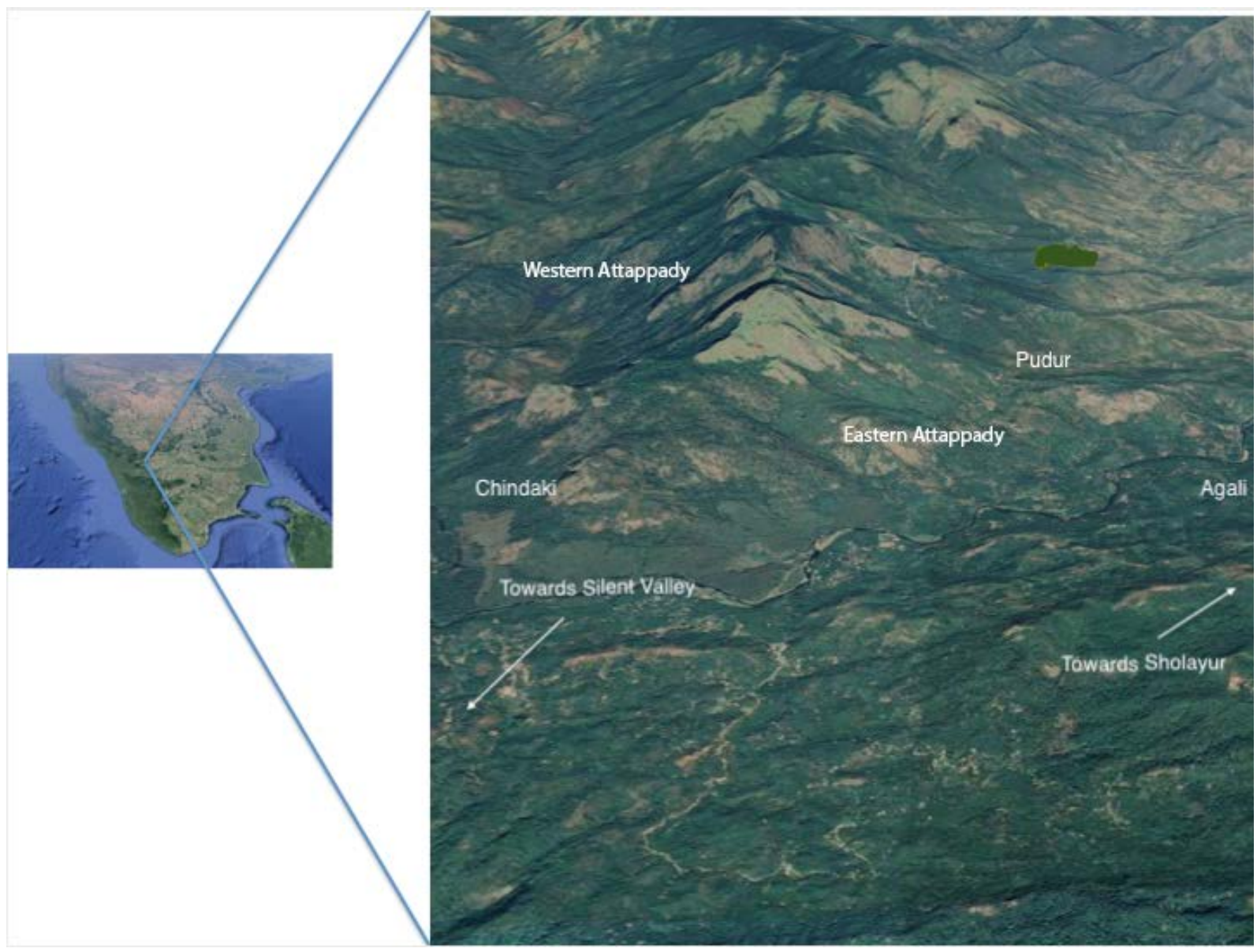

Figure 1. Location of Attappady in Southern India. Source: Google ${ }^{\mathrm{TM}}$ Earth.

Kerala's coastal geography and relative seclusion from the rest of the subcontinent established many of the defining conditions of the larger region's social and political landscape. For several centuries, the region was characterized by three economic geographies that were co-dependent on each other, without any showing 
predominance. The most prosperous actors and those having the most robust network comprised Arabian Sea traders and their allied partners: priests, bankers, merchants, suppliers, and landed protectors; these constituted the commercial sphere, and several elite groups among these gained windfall profits. They operated principally from a narrow coastal plain in the northern part of the state in Malabar. A second group was made up of sovereign powers, principally, the Travancore royal house and landed nobility in the south and coastal towns run by merchant families and landowners in Malabar. Together they characterized the military power of landed family wealth and the coronation of specific lineages to control territory. Their armed support came primarily from low-status peasant-warriors under the control of local Nair chieftains. The Travancore state provided channel and tank irrigation in the southern coastal plains, whose lands were used primarily for wet-rice cultivation, which became the source of substantial rent collection. The third and populous group of Irulas, Kurumbas, Mudugars, Paniyars, and several other Adivasi communities seemed to have discovered the "art of not being governed" and remained largely undisturbed until the mid-20th century in the vast mountainous equatorial forest belts of the Western Ghats (Kumar 1965; Veluthat 2009; Scott 2009).

The two main networks of economic and social authority-commercial merchants and traders (cetti) and upper caste landed nobility (araiyan)—forged a highly hierarchical polity ruled by monarchies (perumāl or rājādhirājā) and their udaiyan, vèlān, and other land-controlling chiefs, land surveyors (nāttār), and other wielders of authority (adhikāri), including military chiefs or sēnāpati. Peasants controlled rights to produce but were under the yoke of local magnates. Territorial power comprised sovereign public authority, or the ability to cause protected or "legitimate" violence on populations that refused conformity to rent collection either openly or clandestinely. Throughout the second millennium CE, there is evidence that sovereign power operated on the basis of a highly rigid caste order, which was only modulated somewhat in the 20th century with the intervention of early social reformers and the rise of communists. In the 19th century, colonial administration of agriculture was manifest through land classification of "land" and "forest", with further instrumental divisions into revenue and non-revenue lands. Through these demarcations, colonial discourse produced new forms of knowledge around property. Nevertheless, most of the earlier systems remained intact through the entrenchment of landed elites as mirāsdārs in Tamil country and armed janmi in Malabar, who continued as rent extractors and local magnates (Kumar 1965; Veluthat 2009; Scott 2009; Raj and Tharakan 2010; Jeffrey 2016).

Governance of Kerala in post-Independence India has been dominated by a parliamentary Marxist left, whose grassroots base made strong appeals to fostering education, sanitation, and health equality for all. In 1951, just a few years prior to the Party's victory in state elections, about two-thirds of the agrarian classes comprised tenants and agricultural labor. The 1969 Kerala Land Reform Amendment Act abolished landlordism and gave kudis or primary producers small but significant rights to property (a tenth of an acre, 0.04ha), creating a new peasantry from erstwhile sharecroppers and foragers and swidden farmers. While the Party developed deep roots in civil society, many former dominant land-owning castes, colonial administrators, and trading communities did not simply relinquish their elite standing but instead managed to form new alliances, some of which benefitted from Party sponsorship. Their continued control over agricultural labor through labor markets allowed for the consolidation of state and market power and its expansion and the infusion of disciplinary/biopower forms, as territorial holdouts. By the 21st century, these processes and the developmental state's social welfare programs shrunk the few remaining spaces of Adivasi subalterns into confined reserves. With the growth of trade and, more recently, its allied economies, tourism, and remittances, land values rose, and Kerala's settler capitalist expansion into the hinterland became further dependent on rents from labor-intensive cash crops. Local labor had little or no modern capitalist agricultural experience and the new colonization of the hinterland changed the life spaces of Irulas, Kurumbas, and smaller clans in the hills and valleys. It also caused them to be displaced to more deficient soils and drier climates, many from the windward areas of north-eastern Kerala's lush Wayanad region into the eastern slopes at Attappady (Desai 2005; Devika 2010; Mannathukkaren 2011).

In Attappady and elsewhere in the Western Ghats, land used to be communally owned, and the Adivasis practiced shifting cultivation that more or less ceased after the Land Reform Act. In the 18th century, local Nair chieftains were allocated control over Attappady by the Zamorin of Kozhikode, the hereditary 
monarch in the Malabar. Until the second half of the twentieth century, however, early settlers found it difficult to traverse malaria-infested forest terrain, thick with vegetation, leeches and wild animals. Around the 1970s, the state began deploying its substantial development machinery to engage in conservation and afforestation projects, even as hydroelectric projects and wind turbines were installed in the hills and settlers from Tamil Nadu and the plains in Kerala expanded their cultivation of cash crops in Adivasi lands. The Forest Department often placed physical structures to mark the boundary of reserved conservation areas, creating enclosures that segmented the landscape and took away lands from Adivasis that they had used for ceremony, cultivation, and foraging for herbs and other forest products while blocking access to traditional routes of passage in the forest. As a result, while individual Adivasis could lay claim to "acres" through pattayam or legal titles, communal land was dispersed and vastly reduced in size, and most commercial land transactions were subject to mediation by powerful brokers. Adivasis lost much of their land as individual plots and communal land to settlers, who deforested large tracts, converting them to cash crop cultivation. Together, these changes completely reshaped land use in the region, principally by territorializing Adivasi and animal corridors and spaces. The resulting geography included areas parceled off into areas under the control of Adivasis (communal land and individual land lots), land owned by settlers, and government land (Velluva 2006; Nirmal 2017).

In 1975, the Kerala Scheduled Tribes Act (Restriction on Transfer of Lands and Restoration of Alienated Lands) was enacted to prevent Adivasi land from going to non-Adivasis. Still, even after it was in operation for several years, only about 5 percent of land rights claimed by Adivasis were restored to them (Xaxa et al. 2014). The switch to cash crops and capitalist markets pushed most Adivasis into debt, and resulted in the loss of their commons and their collective decision-making. Record drought in 1982 and 1986 led to severe grain shortages, with state food distribution systems struggling to cope and creating widespread malnutrition. Adivasi families such as Saroja's lived off a diverse web of resources in these forests before moving to fixed field farming, but even before they could settle into it, market systems arrived, and severe drought years put heavy pressure on agriculture.

In 1998, the Kerala government launched a neighborhood-based program of social work, built on activities of the existing community organizations, but with state support and special emphasis on membership by women. This partly arose out of a political commitment to implement the provisions of enhancing local government as a third branch of government following the 73rd Amendment to the Indian Constitution in 1992, which gave autonomy to village-level governance. Another driver was the Kerala District Councils Act of 1984, which reserved nearly one-third of local seats for women. In Palakkad District, where Attappady is a Block, there are 284 Neighborhood Groups or Kudumbashree, with 43\% participating. In Adivasi areas, participation rates may be significantly higher but have been reported to have less professional support and also less success with collective income-generating programs (Williams et al. 2011). Kudumbashree programs in Attappady made significant achievements in building collective action around non-monetary but community-organizing activities related to nutrition and food, re-igniting some important agroecology activities and self-consciously asserting food sovereignty, as we demonstrate below (cf. Devika and Thampi 2007).

Attappady's Adivasis remember a time when they practiced swidden cultivation on entire hillsides. Panchakaad krishi, or swidden cultivation, refers to rainfed forest patches the Adivasis cultivate, chiefly for millet. In this practice, the entire village prepares the land for cultivation using slash and burn every two years, based on a moral economy where villagers pool their labor for sowing, guarding crops, and harvesting. The grain is mostly used for household consumption and stored until the next time panchakaad is worked. Today, this has shrunk to small pockets further away from the riverine stretches where large tracts of banana have come up. Panchakaad krishi of millet in Attappady is being replaced with cash crop cultivation of banana, cotton, and tree crops like coconut and few spices like pepper. Swidden is still practiced by some Kurumbas and Mudugas deeper in the forest, while most Irulas have switched to cash crops like the settlers. According to Government of Kerala statistics, the three most important crops (by acreage under cultivation) are banana, coconut, and areca nut (from a palm, Areca catechu) (Adam et al. 2018).

In the rain shadow areas of Eastern Attappady, dryland farming is practiced. The Irulas' main crop is banana and the smaller one pigeon pea or tomara on their forest patches. Banana takes a whole year to be 
ready for sale, so just after the rains, they clear their forest patches for tomara. However many Adivasis who were earlier dryland subsistence farmers are now underemployed wage laborers. High dependence on state welfare programs along with soil moisture stress has created a situation of poverty and land degradation on the eastern side of Attappady. Here their reliance on casual work and state welfare has resulted in land having poor productive potential (Purushothaman 2005). The Kurumbas who live deeper in the forest and Mudugas in the buffer zones continue to practice slash and burn agriculture, growing millet mainly for household consumption. Those in interior forest villages do not produce for the market and mainly rely on non-timber forest products for cash.

In Western Attappady, more rainfall meant settlers were able to introduce plantation crops like coffee and pepper. A section of the Irulas also cultivate cash crops here: pepper, ginger, and coffee. Adivasis also lease out their land to settlers and other Adivasis for cultivation. Around half of the Irulas have given their land on lease to non-Adivasis for banana cultivation. Settlers frequently engage Adivasis as wage labor for banana cultivation. 'Leasing out' is common, and fixed rent is paid, replacing earlier sharecropping arrangements. Adivasis usually cannot afford to hire labor themselves, though they sometimes pay their kinsmen for farm work out of a sense of fairness and bonding. Lack of investment and irrigation, pests and disease, and low rainfall have resulted in poor harvests. Comparable conditions have been reported in the Caribbean, where declines in food producing areas are related to the production and marketing of crops such as bananas produced for export, thereby changing dietary preferences and inducing problems in wage labor recruitment that in turn account for decreases in food output (Grossman 1993, 2000).

\section{Nomadic theory: from critical feminist political ecology to collaborative governance}

Feminist political ecologists characterize the Anthropocene as involving capitalism and patriarchy unleashing their inexorable power into the far reaches of the world, spawning the conjoined politics of gender and nature in numerous contexts. The field has reinvented itself, such that there is not just one but multiple feminist politics of the Earth. Identifying the nature-woman-labor nexus helps scholars and activists move towards the materiality of the everyday, with an understanding of how we are embodied and embedded in the Earth's web of life and non-life, with accumulative effects on formations of power and associated cultures of class, ecocide, and patriarchy (Canavan et al. 2010; Povinelli 2006; Salleh 2005). Ariel Salleh's ecofeminism (2005), for instance, expresses an embodied materialism that focuses on the recognition of the othered labor produced by women, Indigenous people, and peasants, whose caring work and productive energies are discounted by the dominant economic and social system. Similarly, Elizabeth Povinelli (2006) points to the need to avoid sequestering or ghettoizing gender and queer issues to a subset of social life, which simply allows for the maintenance of liberal and illiberal forms of power and domination. Yet, the lived realities of Indigenous women and the forests can only be appreciated through situated knowledges (Haraway 1987). Haraway's cyborg destabilizes the category of "nature" and brings technology-driven processes-material and energetic assemblages-into body-land-animal-institution composites. Stacy Alaimo argues that on the one hand, the Mother Earth ecofeminist glorifications of nature play into patriarchal capitalism and, on the other, cyborgs forsake the alliance between women and nature and may lead to technophilia. She proposes instead that women and nature should be seen as "agents in a mutual struggle" (Alaimo 1994). This would strengthen environmental feminisms' political impetus while opposing the appropriation of nature as a passive resource.

More broadly, FPE can be seen as adopting a historical materialist orientation in which gender is one set of relations through which access to and distribution of natural resources is differentiated (Nightingale 2006). It can bring into conversation ecofeminist threads and political economy approaches, while being attentive to subaltern environmentalisms. Yet, it also builds on earlier work and points out that gender-nature traditions are multiple, and in the process of writing of their own histories. Recent strides in scholarship have been to incorporate complexity theories, networks, and affective and materialist theories in human-nature relations (Singh 2018). There are further complexities at work in Tanya Murray Li's ethnographies from Indonesia, showing that governmentality produces subjects and territories but is limited in its reach, and can 
be both caring and untrustworthy ( $\mathrm{Li}$ 2007). Research on water provision in Bangladesh shows class hierarchies were inverted when wealthier families collected water from safe tube wells owned by poorer families (Sultana 2009). Womens' environmental struggles in Kerala also transcend pure categories, like work and protest, and no opposition can be found between caregiving and instrumental manipulation. "These represent theoretical possibilities, extremes in a continuum of practices. The earth care they practice would be located somewhere between these extremes" (Devika 2010). A materialist approach to gender roles is useful because it elucidates the spatial conditions of the livelihoods of gendered bodies, rather than focusing on the identity-laden cultural contexts identified by postmodern theory (Jackson 2001). Critical FPE, addressing such complexities, argues that gender-nature relations are shaped by dualisms of traditional/modern and progressive/anti-progressive, rather than assuming a pro-nature, pro-women stance (Kunze 2017). A binary understanding of complexity, however, does not allow for a dialogue. This article reintroduces the idea of a dialectical conversation across these categories.

Firstly, Marxist analysis, when it destabilizes the centrality of production and work, allows for possibilities in which human beings are connected with each other and with the rest of the natural world (Wood and Foster 1997). Hence, although such an approach sits far from scientific ecology, we suggest the continued relevance of dialectics to ecology from a Marxian perspective (Foster and Clark 2016) using an FPE conceptual framework.

Secondly, a decolonial feminist study of indigeneity in Attappady challenges Eurocentric relations to land as property, suggesting land is part of the networked body of the Adivasi lifeworld (Nirmal 2017). While it offers explanations to understanding Adivasi materiality stemming from postcolonial land practices, highlighting their land struggles and using a relational approach to the world, its 'fourth world' solidarity glosses over the maelstrom of Adivasi contemporary worlds, in which there are also real contestations of capitalism and patriarchy.

While post-structural scholarship on environmental feminism has destabilized nature (Haraway 1991), brought out the mutual agency of women and nature (Alaimo 1994), pointed to embodied materialism of women and Indigenous communities (Salleh 2005) and introduced intersectionality (Li 2015), it has not reflected sufficiently on contradictory processes at work in the forests of the Global South. The decolonial project does not subordinate other ontologies; instead, it encompasses post-humanist, pluriversal worlds, and different epistemes, offering an alternative to Eurocentric universal knowledge (Sundberg 2014). A claim is made that "Indigenous knowledge" has supported the Earth for a long period of time (Simpson 2011). Decolonial scholarship, however, risks romanticizing the Global South while by contrast, Anglo-European theory does not focus substantially on this region. There are limitations, moreover, to the growth- and conservation- centered Western views on sustainability, which the Global South counters with communityled environmental justice movements, especially those with women at the forefront (Rosset 2017; Nagendra 2018).

This situated study navigates these theoretical positions, contributing to critical FPE perspectives of embodied materialism in the Global South. It offers possibilities of interconnectedness of scale from the body to the national and beyond, to build a scholarship that allows for understanding greater complexity (Elmhirst 2011). The history of migration and state-making has led to contested questions of belonging in the context of other parts of the Western Ghats (Menon and Karthik 2019). Nomadic Adivasi practice itself serves as a critique of "sedentarist metaphysics"; the obligation to be rooted results from the valorization of territorialized identities, while mobile ones are considered aberrant (Malkki 1992; Nirmal 2017). The indigenous epistemology of the Adivasis of Attappady is Earth-centered, animal-centered non-Western cosmology, and at the same time, it is already imbricated in capitalism and patriarchal social relations. We suggest that the fluidity of these dialectics in socio-ecological interactions needs to be emphasized. Reinstating movement at the heart of thought is the leitmotif of philosopher Rosi Bradiotti's nomadic thought, which points to future possibilities. Hers is an "affirmative politics" of doing theory and politics, critique and creation. Her nomadic account is of becoming (becoming woman, nomadic, animal, posthuman) (Braidotti 2011). Our ethnographic study substantiates and points to the importance of this becoming. 
We take forward a body of work that shows that land is part of the networked body of the Adivasi lifeworld, even as colonial and postcolonial ideas transform land-use practices (Rocheleau and Nirmal 2015; Nirmal 2017). Our conceptual argument brings the heuristic of dialectic and nomadic movement into feminist political ecology and extends debates on dualisms to propose a more fluid dialectical process. By freeing hitherto frozen categories, we hope to emphasize the intersectional and processual nature of material, cultural and affective dimensions in shaping gender and environment subjectivities. Challenging the conception of humans as homo economicus, ours is a Spinozian perspective which suggests that humans are not only hardwired to maximize utility but are also driven to care, give, and be valued as givers (Singh 2018).

Lastly, we propose that recent approaches of "collaborative environmental governance" help to disaggregate the actions of agents of sovereign authority (the "state") as well as non-state actors working together in multiscale processes of deliberation and ecological innovation. Where successful in promoting deliberative democracy, they may provide useful lessons for envisaging futures in our context (Boyd and Juhola 2015; Westman and Castán Broto 2018; Bennett et al. 2019). By explicitly acknowledging asymmetries and structural challenges of centrality in networks, several of these approaches appear to generate genuine democratic opportunities to subaltern groups in practical contexts, for addressing their intertwined problems of gender, ecology and development (Bodin 2017; Kothari et al. 2019). Notwithstanding the diversity of their conceptual underpinnings, in practice, the most promising of these approaches are marked by processes that seek to engage in continuous learning by doing, alertness to elite capture and enclosures in environmental conflict resolution, and attempts to reduce the sparsity of network ties. The enabling role of state actors in terms of financial and knowledge support is also key, especially when decentralized governance works well (cf. McFarlane 2012).

\section{Methods}

This study involved substantial fieldwork by the lead author in the Attappady Hills, which led to qualitative analysis of ethnographic case studies and narrative analysis. In addition, government reports of the region, forest working plans, and media accounts since the 1960s were researched. Numerous visits to the field were carried out over several months from 2014-2017. A few follow-up telephone calls with key informants were made in 2018 and 2019. Permission was sought for the study in each ooru or village from the village headman or moopan.

Initial meetings with informants were arranged through a primary contact and were followed by interviews in various oorus. The primary contact was a health worker who lived in a convent-run hostel with whom the researcher also stayed during early visits. Several development staff were also accommodated there, and the researcher was subsequently introduced to others in several villages through anganwadi (village childcare center) workers. Throughout the period of the study, the researcher visited a cross-section of oorus inhabited by the Irulas, Mudugas and Kurumbas from those more accessible to those in the interior forest region bordering the Silent Valley National Park. Attappady is administratively divided into three panchayats, or village administrative zones, of Agali, Pudur and Sholayur, which lie in three different climatic areas. One village from each of these climatically diverse zones was closely studied. Agali area receives higher rainfall and has been converted into plantations, and Chindaki village was chosen here. Pudur receives moderate rainfall, and Bommyampadi was studied; Sholayur is the rain shadow area has dryland farming, and Kulakoor Village was the site of study there. Immersion in the field was carried out in 2016 in Attappady, which involved renting a cabin for an initial period from January to June in Nellipathy (in Agali panchayat) near an Irula settlement, and returning to Nellipathy in January 2017 for several weeks.

Participant observation was carried out by spending substantial lengths of time in meetings organized by community animators in oorus, religious festivals, traditional healing centers, and community kitchens. Semi-structured and open-ended interviews were conducted with members of the community in the villages, their fields and forests. During this process key informants were befriended, and with their help, household surveys and focus group discussions were conducted. The ethnographic collection using snowball and convenience sampling was supplemented with interviews of government officials. Snowball sampling was appropriate because it helped connections with different women, each of them uniquely interested in farming 
and Adivasi identity. The researcher's early contacts put her in touch with the others, particularly women farmers who were activists and could speak in Malayalam. This process led to 66 key interviews, which included case studies of Adivasi women farmers and healers which became the basis for narrative analysis. Altogether, however, she had in-depth conversations with more than 200 people, including government officials, journalists, medical staff, and community workers.

During the entire process, field notes, memos, and audio recordings and their transcriptions were maintained. Various themes emerged from our reading of the data and we did a narrative analysis of connected oral histories and interviews (Allen 2017). A social constructivist paradigm was adopted in interpreting the data, which emerged from the many interactions with the communities (Berger and Luckmann 1991). The lead author's position as a Malayalee woman researcher and a non-Adivasi, whose ancestry is from the district of Palakkad in which Attappady lies, undoubtedly influenced her interactions and subsequent interpretation of her fieldwork (cf. Smith 1999).

\section{Findings and discussion}

One May afternoon in 2016, in the forest village of Anavayi, young women were grinding rice flour with their children playing nearby. The men were returning from their forest patches where smoke was still billowing as they were clearing the undergrowth for panchkaad krishi (swidden cultivation of millets). This peaceful evening setting was deceptive, however, for behind it was the unravelling of Indigenous agricultural systems, diets, decision-making bodies and their very worlds. Although some Kurumbas and Mudugas in this region practice swidden cultivation once in three years growing chiefly ragi, or finger millet, they have mostly shifted their diet to rice. Several grow banana and vegetables downhill in Chindaki Village which is closest to the trunk road. The cultivation of millets, ginger, pepper is permitted by the Forest Department in delimited areas. Although some cash crops like banana are being grown in interior villages, transportation is difficult and many travel downslope to labor in commercial production.

Women are keenly involved in farming, especially swidden. "It might seem like panchakaad is done by the men but, even though it is very strenuous labor, we are doing most of it", said a few Kurumba women in Chindaki Village. Adivasi women also have the important role of saving seeds from the crops and vegetables and storing them for the next season. Adivasi women are involved in panchakaad krishi in many key ways; some might even single handedly clear the forests, sow the seeds, keep watch, and harvest the crops. "My mother-in-law was on the malai (hill) doing panchakaad krishi. Until she died three years ago, she grew finger millet, little millet, sorghum, various beans, and pumpkin in the forest. It's only been around 14 years since we started eating rice and, till then, little millet, tubers, and finger millet was our food, although sometimes we also hunted for wild meat", said Saroja from the ooru of Thazhe Moolacombe and one of the Kudumbashree presidents. She and her husband do cultivation together; he does the ploughing while she plants seeds, and weeds and waters the plants. While they have tried banana cultivation, most trees were destroyed, and the main source of their income is from vegetable sales. Many other families like Saroja's, who were raised in pancha krishi, are now trying to integrate into the cash economy.

The settlers to the region brought in banana cultivation, and it symbolizes the switch to cash crops and a cash economy for Adivasis (Sankar and Muraleedharan 1990; Velluva 2006). This also altered their whole system of agricultural practices. Adivasis used to protect their crops by growing yellow flowers to attract insects away from them, but now with the adjoining lands under pesticides, they too have switched to using chemicals. Community-held land has turned into individual landholdings and small family farms, affecting the communal nature of work, the traditional distribution of grains to villagers suffering crop failures, and the importance of decision-making assemblies.

The trunk road between Mannarkad and Coimbatore was constructed in the 1950s, and changed the circulation of commodities. The influx of settlers increased and commercial banana cultivation increased, because of its attractive prices, along with other plantation crops, such as coconut, cotton, and pepper. Irulas who inhabit the region were among the first to switch their cropping pattern from millets to banana. In Western Attappady, more rainfall meant settlers could introduce plantation crops like coffee and pepper. Kurumbas and Mudugas in interior forest villages still do not produce for the market, relying on the sale of 
non-timber forest products when they need cash. Those with some formal education have begun to turn away from swidden and now live downslope cultivating banana, ginger and pepper for the market. Lack of investment and irrigation, crop disease and poor rainfall have resulted in poor harvests.

It is worth noting that in an entirely different context, in the Caribbean, the decline of production in food producing areas has been related to producing and marketing local crops and bananas for export. These, in turn, changed dietary preferences and created problems for wage labor recruitment, accounting for a decrease in food output (Grossman 1993, 2000). In Attappady, in contrast, pattayams, or individual land titles were given to Irulas by the government, which hastened cash crop production for the market. This changed their relation to both land and capital but created similarly adverse consequences to those identified by Grossman in the Caribbean. Many in Attappady voluntarily opted to cultivate banana on their lands. As explained above, Malayalee and Tamil plainspeople took land on lease, and brought Adivasis into wage labor on banana plantations, to the neglect of subsistence cropping. While settlers on wetter hillsides have had success with banana, Adivasis in the rain-shadow areas are now cultivating it and enduring losses. They are sadly optimistic that the next good season will reverse their fortunes and give them respectable disposable income.

The Irulas' main crop is banana together with or tomara (pigeon pea, Cajanus cajan) on their forest patches. Banana takes a whole year to be ready for sale, so just after the rains they clear their forest patches for tomara. Irrigated agriculture has become an attractive on-farm adaptation and diversification strategy (Adam et al. 2018). Still, cultivating banana is a challenge in terms of the care and capital investment required. The crop comes with the promise of making money, but Adivasi farmers we surveyed have lost most of the banana they planted. The households depending on banana cultivation are all in debt. "Even if we invest to get returns on banana, we have to make profits. Otherwise we don't recover our investment. How do we return the money we got from here and there?" asked a farmer.

Tania Li shows that comparable capitalist relations emerging among Indonesian farmers led to the erosion of choice, as they could not retreat from the market to food production when the terms were not good. They have limited capacity to choose the food and farm regime they want. Highlanders, in her studies, entered into global capitalist circuits as a result of their own decisions, such as choice of crops, which alienated them from each other and from the land (Li 2015). Even those farmers in banana cultivation were sometimes found to be malnourished because they were producing for the market, similar to banana exporting economies elsewhere (Grossman 1993). Although banana requires heavy investment and most of the money is borrowed from small businesspeople, the lure of this cash crop is such that it drives large number of Indigenous people to it. Adivasis too borrow from smalltime lenders in the settler community. The arrangement is that the commercial loans are repaid by the Adivasis have to sell the lender their crop at the current rate, deducting the loan repayment each time. A couple said, "I have a loan from a Tamil man in Padavel in the banana business. He gives few people money without charging interest. I have sold my crop to him for three seasons. This year I took a loan of Rs 10,000 (US\$135) from him. Then I stopped borrowing money when I realized there had not been enough rain." Even as farming cash crops became difficult due to lack of rains and capital, the government managed to cover the supply of subsidized rice to the remotest villages.

In Attappady the switch among Adivasis from millets to banana led to lack of household nutritional security, which intermittently exacerbated malnutrition. A few who successfully grew banana increased their cash incomes, and were able to buy motorcycles and spend lavishly on entertainment. "My husband and I have cultivated vazha (banana) in my natal village, so we travel from Agali to Pudur every day on our bike to water the plants", said Gita. Anu, whose seventh month pregnancy was celebrated grandly in the whole village, lost her newborn infant in 2017, probably because of poor nutrition, proving once again that poverty has many hues (Scheper-Hughes 2004).

Women also began to seek state-sponsored rural employment in construction, building water tanks and roads, and today this is their largest source of income. The subsidized supply of rice through the Public Distribution System (PDS) system hastened the dietary decline of tubers and millets, earlier their primary sources of household nutritional security. Kerala has good PDS coverage and supplies all Adivasi households with rice, but it is less nutritive than locally-grown and diverse millet varieties. PDS, as an institution, may 
have increased delivery of calories throughout the country, including Attappady, but it has also changed diets as well. Each family is entitled to 38 kilograms of rice at one rupee (\$0.015) a kilogram. Adivasi women also began to find it easier to cook white rice as millets require substantial time to grind and process.

A PDS shop usually serves a cluster of villages and the men make long trips to fetch and transport the sacks of rice allotted to them. High on a pass in the Attappady hills in Anavayi village, at the crossroad between the interior Kurumba villages and the main Mannarkad Road that connects them, is a tea house run by the moopan (Figure 2). In between sips of tea and bites of sweet dumplings, deep fried dough sweetened with jaggery (cane sugar), sacks of grain can be seen arranged in the corners of the room. The journey from the PDS to the shops is broken at the tea house and the sacks of grain are taken to the various interior villages in subsequent trips. As swidden cultivation is practiced roughly once in three years, there is increased dependence on rice. As mentioned, swidden may only be practiced in fixed zones allotted by the Forest Department and they have no titles for this land.

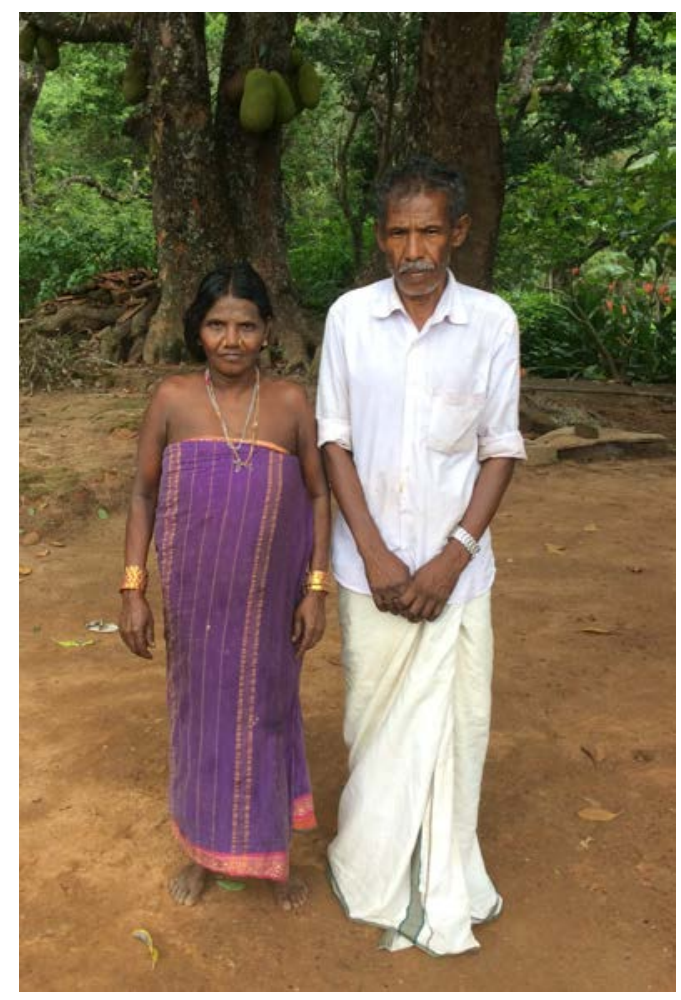

Figure 2: Moopan (village headman) and wife in Anavayi ooru. Source: authors.

Much of the swidden had ceased by the time the Attappady Hills Area Development Society (AHADS) project ended in 2009. AHADS was a roughly US\$5 million project sponsored by the state and financed by the Japanese government to improve biodiversity and advance development in the region (Vishnudas et al. 2012). It brought in wage labor, decreased dependence on agriculture and brought the food culture of the plains up to the hills, even while it increased tree cover and improved water availability in the region. Anish, who is a school teacher in Anavayi, was still in school and helping out in his family farm of 2 acres (0.8 ha) when AHADS started. Like others, his family stopped cultivation and switched to waged labor in construction. Both men and women began to work outside the family farms. "More people who went out to work from home made more money for the household. It was then that we moved to eating rice and even eating three times a day, before that we mostly ate millets and only twice a day", he said. The National Rural Employment Guarantee Scheme has become the biggest employer in the region for Adivasi households. While 
men look for better paid wage labor, most of the women support their households with the rural infrastructure work of these public works programs. As Indigenous systems of social reproduction change, the state's social transfers have mitigated poverty to some extent and improved biodiversity; yet, the very processes that reproduce poverty under capitalism have not been eradicated (Harriss-White 2006). The dry agricultural spells that caused Adivasis to seek wage labor have led to pauperization alongside the loss of the collective nature of access to resources for the reproduction of everyday life. Yet, many Adivasi women responsible for feeding their families have tided over these lean periods with innovations in their everyday life, such as community and kitchen gardens, community kitchens linked to childcare nurseries, and new uses of foraging for medicinal herbs, making them crucial drivers of transformation in the rural economy.

Even as Adivasi women switch to cash crops and aspire to have non-agrarian livelihoods, such as healing, they continue to cultivate patches of land with a mix of crops, have kitchen gardens, and source various vegetables and tubers from the riverbanks and forests near their villages. Women in Attappady raise a type of goat called Attappady Black Gold ${ }^{3}$ and, as they return home from grazing them, they usually bring back some fuelwood, greens, and fruit. Those in the interior villages have to travel long distances to buy vegetables, but grow beans and pumpkins for their households in their own backyards or on common land. Women farmers tend to have more agrobiodiversity in their land with millets, banana, and vegetables interspersed. Similarly, the large-scale switch to banana is accompanied by a rise in medicinal healing. Traditional healing was initially practiced by knowledgeable women healers primarily among their kin, but it has now become sought after by settlers and plainspeople.

One offshoot of the rise of this non-agrarian livelihood is that many women have rapidly transitioned to it and turned into small scale healers. "Our medicines are effective because they are procured from the surroundings. When I see the patient, I go immediately and get it, only then it is effective", said Kumari, explaining the traditional otamooli healing of Attappady. The word literally means a single herb that is used as a cure but the Adivasis use a mixture of herbs for healing. Earlier, the village chief, or moopan, was also the vaidyar, or healer. Over time, as more healers emerged, the men traditionally went to neighboring oorus and treated people. Some even went to nearby towns and treated non-Adivasis for a small fee. Women usually treated children or neighbors and did not charge anything. More recently, plainspeople have begun to arrive for Indigenous herbal cures for variety of ailments. A few centers of healing have been established at various locations run by uncertified but licensed male physicians, although there are many local small-scale healers (mostly women) who are completely dependent on traditional healing.

"I used to accompany my father to the forest and he told me about the plants and how to mix them to make medicine", said Gowriamma, a matriarch and healer of repute in Kulakoor. She and her late husband trained other women in the village in the late 1990s. Gowriamma and others were recognized by the state government as traditional healers and now get annual grants to help with their practice. Kerala's National Rural Livelihoods Mission (NRLM) has also begun to promote cultivation of medicinal herbs as a source of livelihood. While women healers have increased in number, they do not hold positions of authority or have any decision-making roles.

The most renowned healing center in Attappady is the Valliammal Gurukul, named after an Adivasi woman healer who received an award from the state (Figure 3). Still, all healing centers in Chindaki are run by men, but they all pointedly display a photograph of a female ancestor, who they claim they learned medicinal healing from. Most of Attappady's women healers operate independently and only get a few patients in their homes from time to time. Some assist their husbands in preparing and packaging the herbs and take them to alternate centers of healing in Kerala. Gowriamma is vocal for state support to women for opening their own centers. While Adivasi women healers have not been able get much traction in this regard, they have successfully come together to lead an anti-alcohol struggle, which is constitutive of a new gender subjectivity.

\footnotetext{
${ }^{3}$ A adaptable breed, resistant to disease, and also bred and sold.
} 


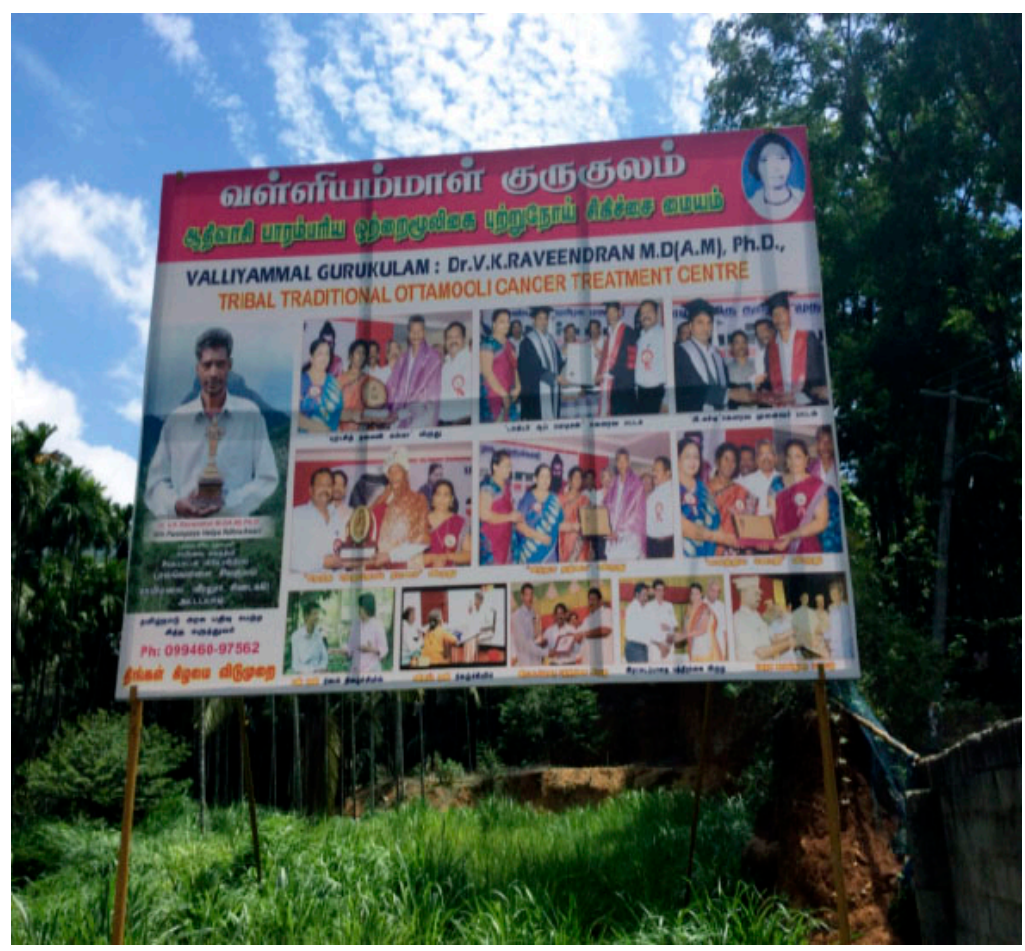

Figure 3: Valliammal Gurukulam. Source: authors.

Dusk had descended on the village, one evening in the summer of 2016. Women were sitting outside under the dim light. Suddenly, loud angry voices and screaming broke out. Gowriamma explained that drunken brawls next door had become commonplace. The husband had a degree in hotel management but was unable to find a job and spent his time drinking. Something similar turned out to be the situation in every ooru. Total liquor prohibition has been in force in Attappady since 1996, which is possibly one of the reasons for illicit brewing of liquor. Alcoholism has brought more suffering to women and children and often leads to domestic disputes. Many Adivasi men spend their earnings on liquor and women typically raise their families single-handedly. Thaikula Sangham, a resource agency for intervention against alcoholism, was registered in 2007 and has been conducting raids where alcohol is being distilled. "When I was leader of the Thaikula Sangam, men came with knives to my house because we conducted raids on illegal distilleries", said one woman. In 2016, when Adivasi men were crossing the state border to Anaikatty to buy alcohol, Adivasi women decided to stage their first hartal, or strike. The anti-alcohol campaign is considered a symbol of revolution among the Adivasi women. "We did not know how to do hartal, vehicles were stopped for the whole day. We didn't know we had to let traffic go in intervals. We also learnt what arrest is as we had gone across the border to Anaikatty and protested, which resulted in the police lathi charging us", said Rajamani from Thaikula Sangam.

The national NRLM was started in Attappady in 2013, with Kudumbashree groups formed exclusively for Adivasi women. Kudumbashree animators under NRLM reached out to the community and served as arbitrators and counsellors on alcoholism and domestic violence. They were trained on the importance of preserving their food culture, seed diversity and organic agriculture. Elsewhere, one of us has argued that agrobiodiversity ought to be a food security right among the Adivasis, in the light of the longer-term government action described above that has served to undermine conditions for foraging, swidden cultivation, and marginal farming (Kozhisseri 2019). In this role, however, state government actors ("street-level bureaucrats" - Pepinsky et al. 2017) served to reinforce agroecology as a means for empowering women. During the lean period in 2013, there was revival of communal forms of reproductive work and community 
kitchens were started. Women began to be at the helm of these, and have since been in charge of getting rations and cooking. Their own traditional foods are cooked here and these kitchens are expected to be converted gradually into nutritional resource centers. They are meant to educate people on their traditional grains, and include narratives and recipes of meals that their ancestors used to eat, along with their nutritional strengths. Kudumbashree has increased women's participation and enabled them to take on positions. Even so, womens' collectives and panchayats have no significant role, and Adivasi women are not yet decision makers in them.

Many conversations with Adivasi informants took place while walking in the forest. Informants described the forest as a space that is incomparable for its fresh air, and the home to animals and deities that have to be respected. "We go into the forest and when we come across an elephant, we just move out of the animal's way. These hills are also home to so many of our deities", said one woman as we walked towards a small shrine in a clearing. Adivasis of Kerala consider the forest their mother, who never abandon them and they have always lived in this home with elephants. "The forest is our home this is our strength and our weakness", said one young man. Although this is changing, they still draw their strength from their relationship with elephants (Janu 2004). Adivasis in the interior forest villages of Attappady have learnt to negotiate the forest and its elephants, which regularly take a few lives. They use sounds by which they acknowledge them respectfully and seek passage. The working relationship between Adivasis and elephants in conservation efforts contains mutual violence and affect, individual intimacies and aggression (Münster 2016).

Animals, forests, hills, and deities are retained in the imagination of Attappady Adivasis even as they shift to cash crops, wage labor and agrarian change transforms them into into state and market subjects. Adivasi women of Attappady negotiate with markets, settlers and development projects but among them, there is also a reassertion of relational Indigenous ontologies and traditional ecological practices. A whole generation of Adivasis have been raised on afforestation and conservation projects, and this has shaped their environmental subjectivities. The Kudumbashree movement, which was designed to mobilize women to form self-help groups, is also creating awareness of ecological sustainability. In Attappady even if men are moving out of the villages for higher wage income and going to towns for seasonal employment, women in the forest villages are tending to their banana groves, kitchen gardens and panchakaad krishi as well as growing medicinal plants in the commons. Adivasi women in Kulakoor village planted medicinal herbs in the schools, to educate their children, and they cooked nutritious meals for them during the lean period in 2013. The ecofeminist concept of the feminine principle based on growing, preserving and promoting diversity seems to continue to sustain households (Mies et al. 1993). In fact there is a continuum of ecofeminism, movements for protection of environment, and a more integrated view of the links between agriculture and the land (Verschuur et al. 2016). During one sundown in Bommyampadi village, Irula women who returned from the Krishnavanam forest grazing goats, collecting fuelwood and fruits, recalled the songs they once sang indicating that forest walks are themselves repositories of collective memory (Gururani 2002). In this song, all sentient creatures are part of the web of creation:

Trusting the soil

Elae lo

The tree lives Ilasa

The tree lives

Ilasa

Trusting the tree Elae lae

The branch lives

Ilasa

La lae la lae La la lae

La lae lae ae

Trusting the branch 
Elae lo

The twig lives Ilasa

The twig lives

Ilasa

Trusting the twigs

The leaves live

Ilasa

Trusting the leaves

Elae lo

Flower lives Ilasa

Flower lives

Ilasa

Trusting the flower

Elae lo

Fruit lives Elae lo

Fruit lives

Ilasa

Trusting the fruits

Elae lo

We live

Ilasa

--Irula song

In the 1980s, close to a hundred Adivasi women were involved in the afforestation of a barren hill that later became a dense forest called Krishnavanam. At the time, the environmentalist Sugatha Kumari became concerned about the disappearance of forests in the Attappady region. Settlers were felling trees, the sandalwood mafia were wreaking damage. Once lush forests had become denuded. She mobilized the entire village of Bommyampadi, especially the women, to take up afforestation. Villagers prepared saplings in packets, planted them, and carried water from a stream to the hill to water the plants. This was the first time the Irula women of Bommyampady had been able to remove themselves from the domestic sphere to become involved in community activities. Marathy, who played a key role in the afforestation, is now a matriarch of the village and other villagers are alert to the goings on in the densely forested Krishanavanam. It is with a certain pride that Bindu said, "For an unlettered people to have brought about afforestation is not a small achievement." This environmental care has a central connection with food. There has been a turnaround among Adivasi women of Attappady to take up "jaiva krishi", or agriculture without pesticides.

Emerging gender and environment subjectivities in Attappady can be considered decolonial. The efforts of local women to learn traditional healing, critically examining the project of modernity, moving to organic agriculture, and strengthening communitarian structures shows that there is a decolonial shift, a process that can be called "delinking." The decolonial option is to practice epistemic disobedience and move away from the categories of occidental and Eurocentric thought to engage with ideas that have been marginalized and discredited as "traditional, barbarian, primitive, mystic" (Mignolo 2011).

To sum up, Adivasi women of the Attappady Hills play a key role in their inventive use of the commons, agriculture, healing, and reconnecting with their Indigenous cosmologies and communities. They mobilize actors that are beyond the human, and become representatives of the wider world. In their roles as conservationists, healers, gardeners, and cooks in community kitchens, they have revived communal forms of reproductive work, even as capital, state, and patriarchal domesticity have challenged their conditions of life. This is a continuous becoming of a 'feminist politics of the earth', a feminist political ecology that can 
only be interpreted through an amalgam of conceptual resources from affect theory, feminist new materialism, posthumanism and nomadic theory to redefine farm, food, care, and land.

\section{Conclusion: unfolding 'feminist politics of the earth' and sedentarization}

We have tried in this article to portray some of the intricately linked but itinerant ("nomadic") social forces operating as dialectical processes that impact agrarian transition among recently sedentarized Indigenous small farmers in the rainforests of South India. In doing so we have described the formation of the Adivasi peasant, arguing that Adivasi foragers and swidden farmers are transitioning to cash crops and capital markets while continuing to retain certain affective ecological ties. In structural-functionalist terms, capital and state have together contributed to the pauperization of these communities and the loss of their commons. Adivasi women are at the forefront of protecting the commons, agrobiodiversity, Indigenous food cultures, and the use of forest products as medicine. They are in a sense "wounded healers" of the body and the Earth, and we find they are leading a rural movement in these hills. Even so, women continue to face patriarchal violence over land access and in their homes, with no significant role in local decision-making.

The Indigenous community of the Attappady Hills, relative newcomers to settled agriculture, have switched quickly and voluntarily to cash cropping for sale to a well-networked and completely marketized agribusiness complex in nearby cities like Coimbatore. Their livelihood strategies, associated development interventions, limited out-migration by younger Adivisas and in-migration by settlers, and conventional chemical-intensive farming practices are altogether ill-suited to maintain secure social and ecological conditions. Indeed, these processes have likely exacerbated vulnerability to climate change (Adam et al. 2018). The agrarian transition been brought about by compound socio-ecological factors conventionally known as "state and market forces" but these are intricately woven together with the land, gender in the forest ecosystem, and the cash crop field system, along with gendered changes in diet and other ways of living. In short, this has been a story about frontier areas of capitalism and patriarchy in the Attappady Hills, where these social forces have resulted in the feminization of labor, disrupting domestic nutritional security in this fragile ecosystem.

These dialectical forces have important consequence for food self-sufficiency and access to the commons. Indigenous people in Attappady occupy what Phillipe Descola calls the "extra-modern world" and are dealing with extractivist capitalism. But they are still inheritors of alternative cosmological systems that cannot be relegated into the past - and just might provide resources to deal with the future (Descola 2013). Indigenous epistemology is not recovery of a pre-capitalist past, but is part of the current capitalist moment. Adivasi worldviews challenge the demarcation between the human and the non-human world (and also life vs. non-life) and point to the fecundity of posthumanist interpretations (Chagani 2014; cf. Povinelli 2006). Translated into policy implications, these findings simply reemphasize the simple demand that Adivasi autonomy over their lands must be upheld, even in conditions where state action claims to be radical, developmentally progressive, or transformative. The Provisions of the Panchayats (Extension to the Scheduled Areas) Act, 1996 (PESA) gave Adivasis right to self-rule and governance and the Forest Rights Act 2006 also gave the village councils the right to protect and conserve forests. Besides, the Western Ghats Ecology Expert Panel in 2011 recommended the implementation of these laws for the devolution of power, and also that $60 \%$ of the Western Ghats should be made into environmentally sensitive zones. Taking these recommendations and rights seriously will go a long way toward restoring collective access to resources and self-governance, and regenerating the commons (cf. Federici and Linebaugh 2018). As things stand, prevailing relationships with state and capital have led to the fragmentation of life, farm, family and rural economy, while bolstering patriarchal norms.

By conceptualizing nomadic and the continuous becoming of feminist politics of the Earth, we hope to raise questions that can help understand the simultaneous threads of materialist and affective political ecology, patriarchal structures and gender subjectivity. A gendered politics of agroecology may yet form in the incipient patterns of deliberative democratic practices. Initiatives such as Kudumbashree may be "stateled", but their transformative republican potential should not be underestimated, as the diverse experiences of La Via Campesina have demonstrated in Latin America (Rosset 2017). How do we understand changing 
land use practice impacting materiality along with gender, health and environment? How do gender-nature conceptualizations reinvent themselves as feminist posthuman concerns that have become more germane in the Anthropocene? We suggest that answers to these questions will help in reimagining Adivasi food sovereignty, agrobiodiversity, forest ecologies and communities. This might also help to rethink conversations in feminist political ecology with influences from nomadic theory, feminist new materialism, emotional political ecologies and feminist posthumanism.

\section{References}

Adam, H.N., D.J. Kjosavik and N. Shanmugaratnam. 2018. Adaptation trajectories and challenges in the Western Ghats: a case study of Attappady, South India. Journal of Rural Studies 61: 1-11.

Alaimo, S. 1994. Cyborg and ecofeminist interventions: challenges for an environmental feminism. Feminist Studies 20(1): 133-152.

Allen, M. (ed.). 2017. The SAGE encyclopedia of communication research methods. Thousand Oaks: Sage.

Banerjee, P. 2016. Writing the Adivasi: some historiographical notes. The Indian Economic and Social History Review 53(1): 131-153.

Bennett, N.J., A.M. Cisneros-Montemayor, J. Blythe, J.J. Silver, G. Singh, N. Andrews, A. Calò et al. 2019. Towards a sustainable and equitable blue economy. Nature Sustainability 2: 991-993.

Berger, P.L. and T. Luckmann. 1991. The social construction of reality: a treatise in the sociology of knowledge. London: Penguin.

Bodin, Ö. 2017. Collaborative environmental governance: achieving collective action in social-ecological systems. Science 357(6352).

Boyd, E. and S. Juhola. 2015. Adaptive climate change governance for urban resilience. Urban Studies 52(7): 1234-1264.

Braidotti, R. 2011. Nomadic theory: the portable Rosi Braidotti. New York: Columbia University Press.

Canavan, G., L. Klarr and R. Vu. 2010. Embodied materialism in action: an interview with Ariel Salleh. Polygraph 22: 183-199.

Cantor, A., E. Stoddard, D.E. Rocheleau, J. Brewer, R. Roth, T. Birkenholtz, K. Foo and P. Nirmal. 2018. Putting rooted networks into practice. ACME: An International Journal for Critical Geographies 17(4): 958-987.

Chagani, F. 2014. Critical political ecology and the seductions of posthumanism. Journal of Political Ecology 21(1): 424-436.

Desai, M. 2005. Indirect British rule, state formation, and welfarism in Kerala, India, 1860-1957. Social Science History, pp.457-488.

Descola, P. 2013. Beyond nature and culture. Chicago: University of Chicago Press.

Devasia, T.K. 2018. Madhu Chindaki lynching: gruesome incident highlights growing threat of 'mobocracy' in Kerala society. Firstpost. March 1. Retrieved from http://www.firstpost.com/india/madhuchindakilynching-gruesome-incident-highlights-growing-threat-of-mobocracy-in-kerala-society4371967.html

Devika, J. 2010. Egalitarian developmentalism, communist mobilization, and the question of caste in Kerala State, India. Journal of Asian Studies 69(3): 799-820.

Devika, J. and B.V. Thampi. 2007. Between 'empowerment' and 'liberation': the Kudumbashree Initiative in Kerala. Indian Journal of Gender Studies 14(1): 33-60.

Drèze, J. and Sen, A. 1990. Hunger and public action. Oxford: Clarendon Press.

Edison, E. and R. Devi. 2019. Tribal land alienation, agricultural changes and food culture transition in Attappady. South Asia Research 39(1): 61-77.

Elmhirst, R. 2011. Introducing new feminist political ecologies. Geoforum 42(2): 129-132. 
Federici, S and P. Linebaugh. 2018. Re-enchanting the world: feminism and the politics of the commons. Oakland: PM Press.

Foster, J. Bellamy and B. Clark. 2016. Marx's ecology and the left. Monthly Review 68(2): 1-25.

Grossman, L.S. 1993. The political ecology of banana exports and local food production in St. Vincent, Eastern Caribbean. Annals of the Association of American Geographers 83(2): 347-367.

Grossman, L.S. 2000. The political ecology of bananas: contract farming, peasants, and agrarian change in the Eastern Caribbean. Chapel Hill: University of North Carolina Press.

Gururani, S. 2002. Forests of pleasure and pain: gendered practices of labor and livelihood in the forests of the Kumaon Himalayas, India. Gender, Place and Culture 9(3): 229-243.

Haraway, D. 1987. A manifesto for cyborgs: science, technology, and socialist feminism in the 1980 s. Australian Feminist Studies 2(4): 1-42.

Haraway, D. 1991. A cyborg manifesto: science, technology, and socialist feminism in the late Twentieth Century. In Haraway, D. Simians, cyborgs and women: the reinvention of nature. London: Routledge. Pp. 149-181.

Harriss-White, B. 2006. Poverty and capitalism. Economic and Political Weekly 41(13): 1241-1246.

ITDP. 2018. https://itdpattappady.kerala.gov.in/2018/03/21/attapady-profile/, accessed June 12, 2020.

Jackson, S. 2001. Why a materialist feminism is (still) possible-and necessary. Women's Studies International Forum 24(3-4): 283-293.

Janu, C.K. 2004. Mother forest: the unfinished story of CK Janu. Women Unlimited, Kali for Women.

Jeffrey, R. 2016. Politics, women and well-being: how Kerala became 'a model'. Berlin: Springer.

Kothari, A., A. Salleh, A. Escobar, F. Demaria and A. Acosta (eds.). 2019. Pluriverse: a post-development dictionary. New Delhi: Tulika Books.

Kozhisseri, D. 2019. Food security rights through agro biodiversity for indigenous people of Attappady Hills, Kerala - a case study. Social Action: a Quarterly Review of Social Trends 69(3): 223-234.

Kumar, D. 1965. Land and caste in South India. Cambridge: Cambridge University Press.

Kunze, I. 2017. Dualisms shaping human-nature relations: discovering the multiple meanings of socialecological change in Wayanad. Agriculture and Human Values 34(4): 983-994.

Li, T.M. 2007. The will to improve: governmentality, development, and the practice of politics. Durham: Duke University Press.

Li, T.M. 2015. Land's end: capitalist relations on an indigenous frontier. Durham: Duke University Press.

Malkki, L. 1992. National geographic: the rooting of peoples and the territorialization of national identity among scholars and refugees. Cultural Anthropology 7(1): 24-44.

Manikandan, A.D. 2014. A tragedy unfolding: tribal children dying in Attappady. Economic and Political Weekly 49(2).

Mannathukkaren, N. 2011. Redistribution and recognition: land reforms in Kerala and the limits of culturalism. The Journal of Peasant Studies 38(2): 379-411.

McDowell, L. 2018. Gender, identity and place: understanding feminist geographies. London: Wiley.

McFarlane, C. 2012. Rethinking informality: politics, crisis, and the city. Planning Theory and Practice 13(1): 89-108.

Menon, A. and M. Karthik. 2019. Genealogies and politics of belonging: people, nature and conservation in the Nilgiri Hills of Tamil Nadu. Conservation and Society 17(2): 195-203.

Mies, M. and V. Shiva. 1993. Ecofeminism. London: Zed.

Mignolo, W. 2011. The darker side of western modernity: global futures, decolonial options. Durham: Duke University Press.

Münster, U. 2016. Working for the forest: the ambivalent intimacies of human--elephant collaboration in South Indian Wildlife Conservation. Ethnos 81(3): 425-447. 
Nagendra, H. 2018. The Global South is rich in sustainability lessons that students deserve to hear. Nature 23 May.

Nalinam, M. 2016. Morbidity pattern of tribes in Kerala. Journal of Humanities and Social Science 21(4): 30-36.

Nightingale, A. 2006. The nature of gender: work, gender, and environment. Environment and Planning D: Society and Space 24(2): 165-185.

Nirmal, P. 2017. Disembodiment and deworlding: taking decolonial feminist political ecology to ground in Attappady, Kerala. PhD Dissertation, Graduate School of Geography. Worcester, MA: Clark University.

Niti Aayog 2018. Infant mortality rate. http://niti.gov.in/content/infant-mortality-rate-imr-1000-live-births Accessed 12 Feb 2019.

Outlook 2018. Hunger, bloodthirst, murder. Outlook India March 12. https://www.outlookindia.com/magazine/story/hunger-bloodthirst-murder/299874 Accessed June 23, 2020.

Parayil, G. (ed.) 2000. Kerala: the development experience: reflections on sustainability and replicability. London: Zed.

Pepinsky, T.B., J.H. Pierskalla and A. Sacks. 2017. Bureaucracy and service delivery. Annual Review of Political Science 20: 249-268.

Povinelli, E.A. 2006. The empire of love: toward a theory of intimacy, genealogy, and carnality. Durham, NC: Duke University Press.

Purushothaman, S. 2005. Land-use strategies for tribals: a socio-economic analysis. Economic and Political Weekly 40(53): 5611-5619.

Raj, K.N. and Tharakan, M. 2010. Agrarian reform in Kerala and its impact on the rural economy-a preliminary assessment. Agrarian reform in contemporary developing countries. Geneva: International Labour Organisation.

Raman, K.R. 2010. Development, democracy and the state: critiquing the Kerala model of development. London: Routledge.

Rocheleau, D.E. 2001. Complex communities and relational webs uncertainty, surprise and transformation in Machakos. IDS Bulletin 32(4): 78-87.

Rocheleau, D.E. 2015. Roots, rhizomes, networks and territories: reimagining pattern and power in political ecologies. In R. Bryant (ed.). The international handbook of political ecology. Cheltenham: Edward Elgar. Pp. 70-88.

Rocheleau, D.E. and P. Nirmal. 2015. Feminist political ecologies: grounded, networked and rooted on Earth. OUP Handbook on transnational feminist movements. Oxford: Oxford University Press. 793-814.

Rosset, P.M. and M.A. Altieri. 2017. Agroecology: science and politics. Leicester: Practical Action Publishing.

Salleh, A. 2005. Moving to an embodied materialism. Capitalism, Nature, Socialism 16(2): 9-14.

Sankar, S. and P.K. Muraleedharan. 1990. Human ecology in Attappady Reserve. In Nair K.K.N. et. al. (eds.). Tropical forest ecosystem conservation and development in South and South-East Asia. Peechi: Kerala Forest Research Institute. Pp. 127-131.

Scheper-Hughes, N. 2004. Death without weeping: the violence of everyday life in Brazil. Berkeley: University of California Press.

Scott, J.C. 2009. The art of not being governed: an anarchist history of upland Southeast Asia. New Haven: Yale University Press.

Simpson, L. 2011. Dancing on our turtle's back: stories of Nishnaabeg re-creation, resurgence and a new emergence. Arbeiter Ring Publishing.

Singh, N.M. 2018. Introduction: affective ecologies and conservation. Conservation and Society 16(1): 1.

Smith, L. Tuhiwai. 1999. Decolonizing methodologies. London: Zed. 
Steur, L. 2009. Adivasi mobilisation: 'identity' versus 'class' after the Kerala model of development? Journal of South Asian Development 4(1) 25-44.

Sultana, F. 2009. Fluid lives: subjectivities, gender and water in Rural Bangladesh. Gender, Place and Culture 16(4): 427-444.

Sundberg, J. 2014. Decolonizing posthumanist geographies. Cultural Geographies. 21(1): 33-47.

The Hindu. 2013. CPI(M) land stir anti-tribal: Janu. https://www.thehindu.com/news/national/kerala/CPIMland-stir-anti-tribal-Janu/article12295349.ece, accessed June 12, 2020.

The Hindu. 2018. Tribal youth beaten to death in Attappady. February 23.

The Hindu 2018b. Unhealthy food choices. February 24. https://www.thehindu.com/news/national/kerala/unhealthy-food-choices/article22846838.ece Accessed June 20, 2020.

Velluva, S. 1999. Dynamics of land use in recently settled forest areas: a case study of Attappady Kerala. $\mathrm{PhD}$ dissertation. Cochin: Cochin University of Science and Technology.

Velluva, S. 2006. Land settlement and degradation: dynamics of land use in recently settled forest areas of Kerala. New Delhi: Serials Publications.

Veluthat, K. 2009. The early medieval in South India. Oxford: Oxford University Press.

Verschuur, C., I. Guérin and H. Guétat-Bernard. 2016. Under development: gender. Cham: Springer.

Vishnudas, S., H.H.G. Savenije and P. Van der Zaag. 2012. Watershed development practices for ecorestoration in a tribal area-A case study in Attappady Hills, South India. Physics and Chemistry of the Earth, Parts A/B/C 47: 58-63.

Westman, L. and V. Castán Broto. 2018. Climate governance through partnerships: a study of 150 urban initiatives in China. Global Environmental Change 50: 212-221.Whatmore, S. and Thorne, L. 2004. Nourishing networks: alternative geographies of food. In T.J. Barnes, J. Peck, E. Sheppard and A. Tickell (eds.). Reading economic geography. London: Blackwell. Pp. 235-248.

Williams, G., V. Binitha Thampi, D. Narayana, S. Nandigama and D. Bhattacharyya. 2011. Performing participatory citizenship-politics and power in Kerala's Kudumbashree programme. Journal of Development Studies 47(8): 1261-1280.

Wood, E.M. and J.B. Foster. 1997. In defense of history: Marxism and the postmodern agenda. New York: Monthly Review.

Xaxa, V. et al. 2014. Report of the High Level Committee on Socio-economic, Health and Educational Status of Tribal Communities of India. Ministry of Tribal Affairs, Government of India. 